\title{
Differences in Reflective Thinking Ability Between Creative Problem Solving and Discovery Learning Models Based on Gender
}

\author{
Ahmad Isnaini* $^{*}$ Mukhtar Mulyono \\ Postgraduate Mathematics Education, State University of Medan, PO BOX 20221, North Sumatera, Indonesia
}

\begin{abstract}
This study aims to see the differences in students' mathematical reflective thinking ability between students which is taught with the Creative Problem Solving learning model and the Discovery Learning learning model if it is viewed from gender. The Data Analysis of research result used two-way Anova to see the effect of gender and learning models on students' mathematical reflective thinking ability. After finding the effect of Gender and the learning model,the advanced test of post-Anova by using the Scheffe' method. The results are as the following : There is Gender influence on students' mathematical reflective thinking ability, there is an influence of the learning model on students' mathematical reflective thinking ability, there is no interaction between Gender and learning models on students' mathematical reflective thinking ability and post-Anova test with Scheffe"s method, the results show that there are differences in mathematical reflective thinking ability between the Creative Problem Solving model and the Discovery Learning model.
\end{abstract}

Keywords: Creative Problem Solving, Discovery Learning, Reflective Thinking Ability

DOI: $10.7176 / \mathrm{JEP} / 10-23-04$

Publication date: August $31^{\text {st }} 2019$

\section{INTRODUCTION}

The actual issue in current learning, especially in the field of mathematics, is how to develop high-level thinking ability and make it an important goal that must be achieved. (Anwar, 2018, pp.91.)In the PISA program that emphasizes high-level thinking ability, there are six levels of student math ability. The achievements of Indonesian students in PISA 2015 only reached 0.8\% from the overall average of 15.3\%. (OECD, 2016)(Muin, 2017, pp 22).

The ability to think at a high level is one of them is reflective thinking. Reflective thinking is a series of logical rational steps based on the scientific method of defining, analyzing and solving problems. Dewey states that reflective thinking is something that is done actively, persistently, and is full of belief supported by clear reasons and can draw conclusions / decide on a solution to the problem given.(Fuady, 2016, p.105).

Tok (2008), in his research to see the effect of the ability of reflective thinking on learning achievement found that reflective thinking ability have improved student learning achievement. (Demirel, 2015, p 2088). Based on research conducted by Nindiasari (2013) in high schools in Tanggerang district, reflective thinking ability are still low. It is shown that almost $60 \%$ of students have not been able to reach indicators of mathematical reflective thinking ability. For example, in the ability to interpret, associate and evaluate. (Jaenudin, 2017, p.71).

The same thing was conveyed by Noer (2010) who conducted a study to see students' mathematical reflective thinking ability. The result is mathematical reflective thinking ability that have an average score of 31.43 with the lowest score of 16 and the highest score of 52. (Nuriadin, 2015, p 256). Masamah (2017) also conducted a preliminary study, obtained information that the ability of mathematical reflective thinking of MAN Ngawi students, the average value of students was 14.2 from a value scale of 0 - 48. (Masamah, 2017, p.3.)

Recognizing the importance of reflective thinking ability, learning must be used as a model that helps develop student learning activeness, student creativity and remains centered on problem solving ability. The ability of students' mathematical reflective thinking can be developed through learning that involves students in finding mathematical concepts that are more emphasized than exploration. The model used in this study is the Creative Problem Solving Model and Discovery Learning Model. The learning process of Creative Problem Solving has steps including: 1) Visionizing or Objective-Finding, 2) Fact-Finding, 3) Problem-Finding, 4) Idea-Finding, 5) Solution-Finding, 6) Acceptance-Finding. The stages in learning using Discovery Learning include: 1) Stimulation, 2) Problem statement, 3) Data collection, 4) Data processing, 5) Verification, 6) Generalization. Thus, research is aimed at determining the influence of learning models on students' mathematical reflective thinking abilities.

This study focused also on the influence of gender on the ability of mathematical reflective thinking after learning with the two models. The results of the Ekasari study (2017) in terms of gender concluded: (a) male students were better able to express mathematical ideas verbally while female students were better able to express mathematical ideas visually and in writing; (b) both male and female students are both able to understand, interpret and evaluate mathematical ideas either verbally, which means that there can be differences in the results of 
mathematical reflective thinking abilities of male and female students after learning. Then the interaction between the learning model and gender in the learning process of mathematics might later affect students' mathematical reflective thinking abilities.

Learning uses different models and the results are analyzed by gender, of course, it will produce a different level of reflective thinking ability between sample classes, so which model can be used more in learning related to the ability to think reflective.

Based on the explanation above, this study aims to see differences in the ability of mathematical reflective thinking between students taught with the Creative Problem Solving learning model and Discovery Learning models based on gender.

\section{METHODS}

The design of this study is Randomized Subjects, Postest Only Control Group Design. Where acting as the independent variable in this study is Gender and Learning Model, while the dependent variable is the ability of students' mathematical reflective thinking.

The study was conducted at Dr Wahidin Sudirohusodo High School Medan on April 23, 2019 until May 3, 2019. The study population was all students of class $X$ in the high school, and randomly taken two classes as an experimental class, namely class X MIA 2 for classes with learning the Creative Problem model Solving and class $\mathrm{X}$ MIA 3 for classes with learning Discovery Learning models. Both classes have the same number of students as many as 36 students in one class.

The two experimental classes were conducted according to each learning model. For technical data collection is done by giving posttest mathematical reflective thinking ability that is with data collection instruments in the form of description questions that have been tested for validity and reliability of the question and in accordance with indicators of mathematical reflective thinking ability.

The posttest data of mathematical reflective thinking ability were analyzed using two-way Anova test, with the data Normality test and data Homogeneity test first as a condition for the two-way Anova test.

Data analysis in this study was based on gender, where in both sample classes, male and female students did not have the same number of students, then the two-way Anova test was carried out with unequal cell counts. TwowayAnova test was conducted to see the influence of the independent variables of the study on the dependent variables in this study. Calculations are done manually using Microsoft Excel and the results are confirmed using SPSS.

After it was found that there were influences between Gender and learning models, even their interactions with students' mathematical reflective thinking abilities, then post-Anova further tests were carried out, using the Scheffe" method, where comparative tests between rows, comparative tests between columns and comparative tests between cells were carried out. in the same row and column. This Scheffe"'comparative test is done to see the differences that occur. If there is no effect of joint interaction between Gender and the learning model on students' mathematical reflective thinking ability, then there is no need to do a comparative test between cells in the same row and column. (Budiyono, 2009, pp.215)

\section{RESULT AND DISCUSSION}

The posttest results of mathematical reflective thinking ability performed at the end of the meeting in the two experimental classes have the descriptions presented in Table 1:

Table 1. Description of the Posttest Results of Reflective Thinking Ability

\begin{tabular}{|c|c|c|c|c|}
\hline Class & $\mathrm{X}_{\min }$ & $\mathrm{X}_{\max }$ & $\overline{\boldsymbol{X}}$ & SD \\
\hline CPS & 63 & 100 & 79 & 9,57 \\
\hline DL & 69 & 100 & 83 & 7,85 \\
\hline
\end{tabular}

Furthermore, the normality test and the homogeneity test of the posttest data were performed using mathematical reflective thinking ability. The results of the normality test and homogeneity test are presented in Table 2:

Table 2. Normality Test and Test of Homogeneity of Posttest Data Reflective Thinking Ability

\begin{tabular}{|c|c|c|c|c|c|}
\hline Class & $\mathrm{D}_{0}$ & $\mathrm{D}_{\text {tabel }}$ & Variance & $\mathrm{F}_{\text {obs }}$ & $\mathrm{F}_{\text {table }}$ \\
\hline $\mathrm{CPS}$ & 0,112 & 0,224 & 91,518 & 1,485 & 1,757 \\
\hline $\mathrm{DL}$ & 0,142 & & 61,632 & & \\
\hline
\end{tabular}

From Table 2 it can be seen for the $\mathrm{D}_{0}$ value of the two experimental classes, smaller than $\mathrm{D}_{\text {table, }}$, so it was concluded that the posttest data mathematical reflective thinking ability in the two experimental classes was

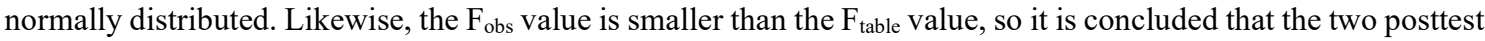
data mathematical reflective thinking ability have homogeneous variances.

After fulfilling the initial requirements of the two-way Anova test, that is, both data must be normally distributed and homogeneous, then the two-way Anova test is carried out with an unequal number of cells. The two-way Anova test results confirmed by SPSS are presented in Figure 1: 
Tests of Between-Subjects Effects

Dependent Variable: Berpikir_Reflektif
\begin{tabular}{|l|r|r|r|r|r|}
\hline Source & $\begin{array}{c}\text { Type III Sum } \\
\text { of Squares }\end{array}$ & df & Mean Square & \multicolumn{1}{c|}{ F } & \multicolumn{1}{c|}{ Sig. } \\
\hline Corrected Model & $689.686^{\mathrm{a}}$ & 3 & 229.895 & 3.135 & .031 \\
Intercept & 471263.552 & 1 & 471263.552 & 6425.505 & .000 \\
Gender & 360.856 & 1 & 360.856 & 4.920 & .030 \\
Model & 304.125 & 1 & 304.125 & 4.147 & .046 \\
Gender * Model & 66.693 & 1 & 66.693 & .909 & .344 \\
Error & 4987.300 & 68 & 73.343 & & \\
Total & 480827.000 & 72 & & & \\
Corrected Total & 5676.986 & 71 & & & \\
\hline
\end{tabular}

a. $\mathrm{R}$ Squared $=.121$ (Adjusted $\mathrm{R}$ Squared $=.083$ )

Figure 1. Confirmation of the Two-Way Anova Test using SPSS.

To test hypotheses using calculations through SPSS, taking into account the significance of the test results. If the value is Sig. smaller than 0.05 , alternative hypothesis can be accepted. In the Gender influence test on students' mathematical reflective thinking ability, the Sig value was obtained. 0.030 is smaller than 0.05 , which means that Gender has an influence on students' mathematical reflective thinking abilities.

In the effect of the learning model test, both the Creative Problem Solving model and the Discovery Learning model on students' mathematical reflective thinking ability, the Sig value was obtained. 0.046 is smaller than 0.05 , which means that the use of the learning model affects students' mathematical reflective thinking ability.

Furthermore, on the effect of joint interaction between Gender and learning models on students' mathematical reflective thinking ability, the Sig value is obtained. 0.344 is greater than 0.05 , which means that there is no interaction between Gender and Learning Model on students' mathematical reflective thinking ability.

After there is influence from Gender and the learning model on students' mathematical reflective thinking ability, but not the interaction, which model is then determined to be better by carrying out a post-Anova test using the Scheffe" ' method. The results of further tests using the Scheffe' method are presented with a mean between cells in Figure 2:

\begin{tabular}{|c|c|c|c|c|}
\hline \multirow{2}{*}{ Gender } & \multicolumn{2}{|c|}{ Model } & \multirow{2}{*}{ Sample } & $\begin{array}{c}\text { Marginal } \\
\text { Average }\end{array}$ \\
\cline { 2 - 3 } & CPS & DL & & \\
\hline Male & 63,74 & 63,25 & 35 & $\mathbf{6 3 , 4 9}$ \\
\hline Female & 68,71 & 63,40 & 37 & $\mathbf{6 6 , 0 5}$ \\
\hline Sample & 36 & 36 & & \\
\hline Marginal Average & $\mathbf{6 6 , 2 2}$ & $\mathbf{6 3 , 3 3}$ & & 64,773 \\
\hline
\end{tabular}

Figure 2. Average Between Cells

Next, a comparison test between lines is performed, with the computational results summarized in Table 3: Table 3. Inter-Line Comparison Test

\begin{tabular}{|c|c|c|c|c|}
\hline Comparation & $\mathrm{H}_{0}$ & $\mathrm{H}_{\mathrm{a}}$ & $\mathrm{F}_{\text {obs }}$ & $\mathrm{F}_{\text {tabe }}$ \\
\hline$\mu_{1} v \boldsymbol{s} \mu_{2}$ & $\mu_{1}=\mu_{2}$ & $\mu_{1} \neq \mu_{2}$ & 5,03 & 3,92 \\
\hline
\end{tabular}

From Table 3 it is obtained that the value of $F_{\text {obs }}$ is greater than the value of $F_{\text {table }}$ which is $5.03>3.92$, which means that $\mathrm{H}_{0}$ is rejected. $\mathrm{H}_{\mathrm{a}}$ is accepted, it can be concluded that there is a significant difference between male gender and women's gender. Based on Figure 2 above, the marginal mean for male gender is 83.31 and female gender is 78.81 , so it can be concluded that male gender has mathematical reflective ability that is better than female gender.

Followed by a comparative test between columns, with computational results summarized in Table 4:

Table 4. Inter-column Comparative Test

\begin{tabular}{|c|c|c|c|c|}
\hline Comparation & $\mathrm{H}_{0}$ & $\mathrm{H}_{\mathrm{a}}$ & $\mathrm{F}_{\text {obs }}$ & $\mathrm{F}_{\text {tabel }}$ \\
\hline$\mu_{1} v \boldsymbol{s} \mu_{2}$ & $\mu_{1}=\mu_{2}$ & $\mu_{1} \neq \mu_{2}$ & 4,25 & 3,92 \\
\hline
\end{tabular}

From Table 4 it is obtained that the value of $F_{\text {obs }}$ is greater than the value of $F_{\text {table }}$ which is $4.25>3.92$, which means that $\mathrm{H}_{0}$ is rejected. $\mathrm{H}_{\mathrm{a}}$ is accepted, it can be concluded that there is a significant difference between the Creative Problem Solving model and the Discovery Learning model. Based on Figure 3 above, the marginal mean for the Creative Problem Solving model is 78.99 and the Discovery Learning model is 83.12, so it can be concluded that the Discovery Learning model provides mathematical reflective thinking ability that are better than the Creative Problem Solving model. 
Comparative tests between cells in the same row and in the same column do not need to be done because in the Anova test results, no interaction between Gender and the learning model was found on students' mathematical reflective thinking ability.

\section{CONCLUSION}

Based on the results of research data analysis on mathematical reflective thinking ability taught by the Creative Problem Solving and Discovery Learning models, some conclusions are obtained as follows: 1) Learning models both Creative Problem Solving and Discovery Learning models are used as learning models in both experimental classes influences students' mathematical reflective thinking ability. 2) Gender also has an influence on the ability of mathematical reflective thinking. 3) There is no interaction between learning models and gender on students' mathematical reflective thinking abilities. 4) There are differences in students' mathematical reflective thinking ability between the two learning models if viewed from gender. Male students have mathematical reflective thinking ability that are better than female students and Discovery Learning model provide results of mathematical reflective thinking ability that are better than the Creative Problem Solving model.

\section{References}

Anwar, Sofiyan, 2018, Teoritik Tentang Berpikir Reflektif Siswa Dalam Pengajuan Masalah Matematis, Jurnal Numeracy, Vol. 5, No1, April 2018, pp 91 - 101.

Budiyono, 2004, Ststistika Untuk Penelitian, Surakarta: Sebelas Maret University Press.

Demirel, Merek, \& Ipek Derman, \& Edibe Karagedik, 2015, A Study on the relationship between reflective thinking ability towards problem solving and attitudes toward mathematics, Procedia - Social and Behavioral, pp 2086 - 2096. http://doi.org/10.1016/j.sbspro.2015.07.326

Ekasari, Dian Fitri, 2017, Kemampuan Komunikasi Matematika Siswa Ditinjau Dari Gender Kelas VII Smp Negeri 2 Kembang Tahun Ajaran 2016/2017, Skripsi, tidak dipublikasikan, Universitas Muhammadiyah Surakarta.

Fuady, Anies, 2016, Berfikir Reflektif dalam Pembelajaran Matematika, Jurnal Ilmiah Pendidikan Matematika, Volume 1 Nomor 2, pp 104 - 112, P-ISSN: 2502-7638; E-ISSN: 2502-8391

Jaenudin, \& Nindiasari, \& Pamungkas, 2017, Analisis Kemampuan Berpikir Reflektif Matematis Siswa Ditinjau Dari Gaya Belajar, Prima: Jurnal Pendidikan Matematika, Vol. 1, No. 1, Juli 2017, pp. 69-82, P-ISSN: $2579-$ 9827, E-ISSN: 2580-2216

Masamah, Ulfa, 2017, Peningkatan Kemampuan Berpikir Reflektif Matematis Siswa SMA Melalui Pembelajaran Berbasis Masalah Ditinjau Dari Kemampuan Awal Matematika, Jurnal Penelitian Pendidikan Matematika, 1 (1), pp 1-18.

Muin, Abdul, \& Lisfa Novianti, \& Eva Musyrifah., 2017. Analysis of Mathematical Reflective Thinking Ability Based on Learning Model And Mathematical Prior Knowledge. Advances in Social Science, Education and Humanities Research, volume 115: $3^{\text {rd }}$ ICEMS 2017.

Nuriadin, Ishaq, et.all. 2015. Enhancing Of Students' Mathematical Reflective Thinking Ability Through Knowledge Sharing Learning Strategy In Senior High School. International Journal of Education and Research.Vol. 3 No. 9 September 2015, pp $255-268$. 